\title{
ВЗАИМОСВЯЗЬ ЗНАНИЯ, МНЕНИЯ И ВЕРЫ: ГНОСЕОЛОГИЧЕСКИЙ АНАЛИЗ
}

Процесс формирования знания включает в себя такие промежуточные «незрелые» познавательные формы, как мнение и вера. Соответствующие им термины естественных языков употребляются чаще всего как взаимозаменяемые, в некоторых же языках для их фиксации применяется в ряде случаев одно слово. Примером может служить английское слово «belief».

В современной философской, частнонаучной и публицистической литературе, как правило, не разграничиваются, считаются синонимами. Причем, в отдельных случаях предпочтение слова «мнение» слову «вера» базируется на предвзятом отношении ко второму, возникшему в результате закрепления за ним религиозного смысла. Неразграниченность этих терминов связана также и со сходными функциями обозначаемых ими явлений: как мнение, так и вера, подобно самому знанию, определяют или, по крайней мере, стимулируют практическую деятельность человека, выполняя роль связующего элемента между ними.

Являясь моментом любого вида социальной деятельности, мнение и вера выступают «промежуточным звеном между знанием и практическим действием...» (Копнин 1974: 252). Роль мнения и веры, как специфических ориентиров человеческой деятельности, в метафорической форме выявляет Д.М.Армстронг. Совокупность мнений и верований, которые управляют, руководят, направляют и контролируют наши действия, он уподобляет «плану», «схеме» (map), своеобразной географической карте, с помощью которой путешественник передвигается по местности. «Верования» (belief) - это карты, - по его мнению, в свете которых мы готовы действовать» (Armstrong 1973: 34).

Несмотря на прочную традицию недифференцированного употребления терминов «мнение» и «вера», сходные функции и одинаковую природу соответствующих феноменов, они всё-таки разные. Наиболее явно они различаются между собой своими психолого-гносеологическими характеристиками и местом в познавательном процессе.

\section{Особенности мнения и его отношение к}

знанию. Мнение как гносеологическая категория и ее отношение к знанию привлекло внимание философов, которые рассмотрели их в ряде диссертационных исследований и публикаций (Ерунов 1971; 2003).

Б.А.Ерунов, впервые поставивший задачу гносеологического анализа мнения на принципиальной новой основе, а вслед за ним и А.Г.Волов, конкретизировавший гносеологические аспекты соотношения знания и мнения, показали, что проблема эта не нова, в классической философии сложились устойчивые традиции как изолированного, так и совместного их осмысления.

Имевшие же в ней место резкое противопоставление знания и мнения, с одной стороны, и полное их отождествление, с другой, определялись рядом причин:

- признанием возможности лишь двух результатов познания - знания и незнания,

- полным абстрагированием от познающего субъекта и игнорированием его воздействий на содержание результатов познания,

- предположением неизменности знания как противоположности изменчивого и субъективного мнения. 
Преодоление этих ограниченных установок, учет активной роли гносеологического субъекта позволяет рассмотреть мнение в качестве такого самостоятельного познавательного образа, который может быть как истинным, так и ложным. Независимо от своих свойств, этот образ принимается субъектом и полагается им в качестве истинного и достоверного. Мнение в этом смысле - это не знание, а всего лишь претензия на него. Его возникновение и существование определяется моментами неопределенности в познании. Психологически это выражается в сочетании степеней уверенности и сомнения, гносеологически - в частичной адекватности и в частичной (для определенных условий) объективной обоснованности.

Итак, учитывая результаты проведенного Б.А.Еруновым и А.Г.Воловым анализа, мнение можно определить как класс суждений, характеризующийся «степенью уверенности и объективной обоснованности» (Ерунов 2003: 180). Уверенность при этом возникает на основаниях, недостаточных как с объективной, так и субъективной точки зрения. Такое понимание гносеологической специфики мнения позволяет определить знание как «удостоверенное истинное мнение» (Оганян 1984).

Отграничивая знание от мнения вообще, от истинного мнения в частности, нельзя не учитывать возможности их взаимного «превращения». Не только мнение «переходит» в знание, но знание, точнее, то, что считалось знанием, при дискредитации оснований его истинности может стать мнением.

«В практике познания, - замечает в этой связи С.Б.Крымский, - знание, ставшее ложным, post factum всегда объявляется мнением или просто иллюзией знания» (Крымский 1974: 33).

Соотношение веры и знания. Исторически сложилось так, что обыденное словоупотребление допускает, как и в случае со знани- ем, чрезвычайную неопределенность термина «вера». Так, в «Словаре русского языка» она определяется:

- как «твердая убежденность», «уверенность в чем-либо»;

- как состояние сознания, связанное с признанием существования бога, чеголибо сверхъестественного;

- как «доверие»(Вера 1952: 186).

Такая неоднозначность характерна не только для русского, но и также, например, для английского языка. В знаменитом словаре Вебстера приводится шесть его значений:

- «состояние веры»;

- «убеждение, что определенные вещи истинны»;

- «вера (религиозная)»;

- «доверие, уверенность»;

- «принятие или согласие с чем-то заслуживающим доверия, реальным»;

- «что-то, во что верят или принимают как истинное»;

- «мнение (an opinion)», «ожидание, суждение»;

- «вероучение, кредо или доктрина» (Belief 2002: 135).

Очевидно, что при таком разнообразии значений психологогносеологическая специфика веры не улавливается. Она проясняется в результате специального конкретнонаучного и философского анализа.

Внимание, интерес философов к проблеме веры и её отношению к знанию были постоянными и неустанными. Уже в античное время, начиная с Элейского периода развития философии, значение чаще всего сопоставлялось с особой гносеологической ситуацией и её продуктом-доксой. Впервые вывод о том, что не любой результат познания может быть назван знанием, в строгом смысле слова сделал в процессе размышления над господствующими в обществе в то время обыденными и мифологическими представлениями о мире Ксенофан. 
В дальнейшем Парменид в поэме «О природе» поддержал ту идею, что наряду со знанием существуют не всегда истинные, не всегда достоверные, колеблющиеся мнения и верования.

Почти все античные философы понимали под доксой такие представления людей, которые возникали у них либо в результате чувственного восприятия многообразных, случайных вещей, либо в результате некритического отношения к авторитетным сообщениям других людей. Чувственная достоверность или ссылка на авторитет считались необходимыми и достаточными условиями существования доксы, а также и ее признаками. С ними было связано признание характерно для неё, в отличие от знания, субъективности, относительности и смутности.

Процесс постижения многообразия преходящих явлений, в результате которого и возникает докса, Демокрит назвал «темным родом» познания. Поскольку докса не обоснована, не объяснена, бытие в ней не отделяется от небытия, постольку она принимается за действительное знание, причем в таких случаях ей придается объективность, истинность и достоверность.

При общем критическом и даже отрицательном отношении такого рода «знанию» софисты, наоборот, стремились выдавать его за подлинное знание, употребляя правдоподобные посылки при доказательстве его истинности, либо допуская сознательные искажения в процессе обоснования заведомо ложного утверждения. Теоретические выводы софистов, производные от их практической деятельности «учителей мудрости», характеризовались отрицанием всеобщего, объективного или хотя бы интерсубъективного знания и признанием возможности существования лишь частных мнений, верований, смутных предположений, догадок и т.п. Познание было сведено ими к процессу достижения единственно реальных, по их мнению, относительных, субъективных результатов, объединяемых понятием «доkca».

Полемизируя с софистами, Сократ, Платон, Аристотель показали, что такое свойство доксы, как её неопределенность, выражающаяся в сочетании знания (единичного, преходящего) и незнания (общего, существенного), не дает ей права быть единственным или конечным продуктом познания. В силу таких противоречивых свойств, она может быть только промежуточным результатом, который, по мнению Платона, «темнее» знания и «светлее» незнания (Платон 1971: 282). . Коль скоро предметом доксы является то «многое», которое колеблется между становящимся миром и абсолютным, то может существовать несколько образов изменяющегося предмета, соответствующих ему в разной степени, истинных и неистинных. Такое понимание закрепил Аристотель, который выделяя доксу в качестве особого, самостоятельного по отношению к знанию познавательного продукта, полагал, что «мнение бывает в том, что хотя и истинно или ложно, не может быть иначе. А это и есть схватывание неопосредованной, но не необходимой посылки... Мнение есть нечто непостоянное, и такова его природа» (Аристотель 1983: 313).

Таким образом, важнейшим результатом философского осмысления отношения знания и доксы в античной философии явилось признание последней, хотя относительным, неустойчивым, неопределенным, иногда неистинным и недостоверным, но всё-таки необходимым элементом, этапом движения от полного незнания к знанию - истинному и обоснованному постижению человеком действительности.

Несмотря на забвение специфических античных терминов «эпистема» и «докса» в дальнейшем, исследование обозначаемых ими явлений не прекращалось. 
В средневековых философско-теологических системах интерпретация их взаимосвязи отличалась неоднородностью. Тер-туллиан, мышление которого тяготело к парадоксам, объявил разум (=научному знанию, знанию вообще) предрассудком античности. Он сформулировал своё кредо: «верую, потому что абсурдно», тем самым утвердив враждебность веры (религиозной) обоснованному знанию (науке). Резкое противопоставление их оказалось неприемлимым для Августина, стремившемся подвести под религиозную веру философско-научную базу. С этой целью он выдвинул тезис о тождестве веры и знания при господствующем положении веры. Она должна, с его точки зрения, предшествовать знанию и пониманию. «Верь, чтобы понимать», - призвал Августин (Соколов 1999: 65).

Ансельм Кетерберийский в трактате «Монолог» решительно поставил веру выше знания. По его мнению, надо стремиться размышлять не для того, чтобы верить, а верить, чтобы понимать. Вера предшествует разуму и ее положения составляют норму для него, вместе с тем и вера «ищет разумения» (Соколов 1999: 138-139).

Отсутствие противоречия между знанием и верой, «правильным разумом» и «истинным авторитетом» доказывал И.О.Эриугена. Не противопоставляя их, подчеркивал преимущество знания перед слепой верой П.Абеляр. Наиболее значительным усилием, направленным в тот период на решение проблемы соотношения знания и веры, был томизм. Доказательства их совместимости, представленные влиятельным Фомой Аквинским, а даже более того - их гармонии, имели своей конечной целью, безусловно, подчинение разума вере (Желнов 2001). Вера и знание, с его точки зрения, как бы произрастает из одного корня, имеют один и тот же источник и на этой основе как бы дополняют друг друга. Это как бы два пути, ведущие к одной и той же цели.
В теории двойственной истины разум (знание) и вера были признаны двумя равноправными, автономными областями. Разум, в отличие от ряда теорий, был представлен в ней самостоятельным, независимо от веры обосновывающим свои истины.

В новое время Б.Спиноза, исследуя способы познания, выделил три возможных пути: только через веру (происходящую из опыта или понаслышке), через истинную веру и посредством ясного и отчетливого познания. Первый путь, по его мнению, подвержен нередко заблуждению. Второй и третий, хотя и различаются между собой, не могут заблуждаться (Спиноза 2003: 113).

Д.Локк не просто различал знание и веру, но противопоставлял их друг другу: «В чем бы ни заключалось, по нашему мнению, познание (knowledge), - полемизировал он со своими противниками, - ставим ли мы достоверность на такое основание, которое дает миру мало или совсем не дает никакого познания... Это вовсе не затрачивает и даже не имеет никакого отношения к надежности веры, которая совершенно отлична от знания, не стоит и не падает вместе со знанием» (Локк 1987: 385). Под верой Д.Локк предложил понимать «...наше согласие с каким-нибудь предложением, как с истинным, хотя и относительно его истинности мы не имеем достоверного знания» (Локк 1987: 72). Противопоставляя знание и веру, он вместе с тем и намечал пути перехода одного в другое. «... Когда вера доведена до достоверности, - считал он, - она разрушается. Тогда это уже более не вера и знание» (Локк 1987: 385). В дальнейшем Д.Юм, скрупулезно исследуя природу веры самой по себе, указал явную нетождественность её знанию. «Идея объекта, - писал он, - является существенной частью веры в него, но не исчерпывает последней. Мы представляем себе много вещей, в которые не верим» (Юм 1995: 120). Он заключил, что между простым представ- 
лением существования какого-нибудь объекта и верой в это существование большое различие. Выясняя это различие, Д.Юм в конечном счете отождествил все познавательные результаты с верой в силу недостижимости, по его мнению, достоверного знания.

Позицию И.Канта о соотношении знания и веры характеризует его известное высказывание, где он признался в том, что ему пришлось «...ограничить (aufheben) знание, чтобы освободить место вере» (Кант 1998: 95). Верой же он назвал тот случай, когда «признание истинности суждения имеет достаточное основание с субъективной стороны и в то же время считается объективно недостаточным...» (Кант 1998: 673).

Гегель как представитель рационализма «растворил» веру в знании, говоря, что «...вера и мышление суть оба знание» (Гегель 1935: 412), что они едины, что вера как «чистое сознание сущности» есть не что иное, как разновидность знания. Для него верить вместе с тем означает «не что иное, как не быть в состоянии продвинуться к определенному представлению, не желать входить в дальнейшее рассмотрение содержания» (Гегель 1956: 363).

«Заместителем», «спасителем» знания вера предстает в концепции С. Къеркегора. Он подчеркнул антагонизм веры и знания, дискредитируя, умаляя, принижая и даже устраняя последнее как помеху и преграду на пути к безграничной, безраздельной и фанатичной вере. Вера, по его мнению, не имеет ничего общего со знанием. «Как можно доказывать то, что основано на вере? - спрашивал он, сам же отвечал на свой вопрос. - Вера не терпит доказательства, она должна рассматривать его как своего врага» (Быховский, Къеркегор 1972: 108-109).

Отличить истинную веру от знания как такового можно, по мнению современных западных авторов, по «критическому» признаку последнего - обоснованности (Rynin 1967: 10).
Вместе стем, знание нередко сводится ими к истинной и оправданной (обоснованной) вере (Ayer 2006: 34). Такое утверждение подвергается критике с точки зрения в понимании оснований уверенности, с одной стороны. Сдругой стороны, ему противопоставил свою концепцию К.Поппер. Если знание понимать как «особо гарантированный (assured) род веры человека», то это будет, своего рода, субъективизм, по его мнению. Рассчитывая порвать с этой «субъективной ошибкой», он предложил устранить из эпистемологического словаря все «субъективистские» и «психологические» термины и особенно термин «вера» (belief). Он стремится перевести их в объективные, с его точки зрения, термины. «Таким образом, вместо того, чтобы говорить «вера», - пишет К. Поппер, - я говорю об “утверждении» или об «объясняющей теории»..., а вместо высказывания «оправдание» (justification) веры» я говорю об «обосновании утверждения, что некоторая теория истинна» (Popper 1972: 25).

По его мнению, предложенный им принцип перевода понятий гарантирует преодоление юмистского иррационализма, субъективизации и психологизации знания. Ясно, однако, что дело в данном случае не в терминах и не в манипуляциях с ними, не в названиях познавательных явлений. Для того, чтобы понять действительное соотношение знания и веры, необходима содержательная интерпретация этих феноменов на основе обобщения историкофилософского материала.

Общим итогом рассмотрения данной проблемы в классической и современной западной философии является признание веры, (в отличие от знания - истинной и достоверной формы постижения человеком мира), таким познавательным результатом, который может быть как истинным, так и ложным, поскольку обоснованность её носит субъективный и недостаточный характер. 
Но, несмотря на постоянное внимание, проблемы веры и ее отношения к знанию не получила в классической европейской философии достаточной разработки. Это, кстати, констатировал ещё в своё время Гегель. «Так как эти категории, - писал он в «Энциклопедии философских наук» о «знании», «вере» и подобным им, - предполагаются известными, то их слишком часто употребляют согласно одним лишь психологическим представлениям и различениям; но их природа и понятие - то, что единственно важно, не исследуются» (Гегель 1974: 187).

В литературе вера как таковая, как феномен познания достаточно обстоятельно еще не проанализирована. Ей посвящены лишь отдельные небольшие работы и статьи (Козырева 1988; Борунков 1989; Ерунов 1971; Хомутовский 1971; Щербаков 1972; Аверин 1998; Геворкян 1987; 1987; 2010; Манасян 1973; Оганян1990).

Это объясняется рядом причин и, в частности, тем обстоятельством, что она до недавнего времени рассматривалась преимущественно в религиоведческой, атеистической и психологической литературе.

В результате признания и абсолютизации положения о вере как сверхъестественной стержнепсихологической структуры личности религиозного человека, делался вывод о том, что «вера может быть только религиозной», что «никакой другой идеологии (кроме религиозной)» чувство веры не свойственно; другие идеологии опираются на знание.

Следствием такого рода суждений и явилось уже отмеченное здесь закрепленное за понятием «вера» сугубо религиозного содержания, что отразилось и в "Новой философской энциклопедии», включающей только такую её экспликацию, т.е. как «слепой убежденности в существовании «сверхъестественного мира» (Вера 2000: 380).
Явное освобождение понятия веры от сугубо теологического содержания в марксистской литературе началось в конце 60-х - начале 80-х годов. В этот период появился целый ряд работ, в которых четко прозвучала мысль о том, что неправомерно рассматривать веру в качестве специфически религиозной категории, свойственной лишь религиозному сознанию. Она является необходимым элементом общественного индивидуального сознания, неотъемлемым моментом любого вида общественной деятельности (П.В.Копнин, Ю.Ф.Борунков, В.Р.Букин, Б.А.Ерунов, Г.Клаус, В.И.Губенко и др.). Вторая причина отсутствия развернутого марксистского анализа веры как гносеологического явления заключается в том, что она была монополизирована также и психологией. В ней вера рассматривалась как элемент психологической структуры личности, как феномен сознания.

В зависимости от того, какая сторона, какой элемент ее структуры оказывался в центре внимания, природа веры идентифицировалась с отдельно взятыми компонентами психики: либо с эмоциями, либо с волей, либо с мыслительными (интеллектуальными, «разумными») процессами.

Анализ позволяет присоединиться к имеющейся в нашей литературе условной классификации всех классических философско-психологических концепций ее природы, включающей так называемые «эмоциональные», «волевые» и «интеллектуальные» (А.К.Козырева).

Суть «эмоциональной» теории заключается в выявлении и признании того факта, что верования представляют собой эмоциональные установки, выражающие отношения людей к достигнутым познавательным результатам. Эмоция уверенности при этом считается «минимумом веры», её «основанием», «стержнем». Классическим образом такой интерпретации веры является юмовская концепция, в которой она была представлена как «бо- 
лее яркое, живое, принудительное, устойчивое и прочное представление какого-нибудь объекта, чем то, которого мы могли бы когдалибо достигнуть с помощью одного только воображения» (Юм 1995: 52). Пытаясь уловить и отобразить специфику этого сложного чувства, он связывал его с «особой силой», «живостью», «прочностью», «твердостью», «стойкостью» и т.п.

Практическое функционирование веры тесно связано с волевым началом человеческой личности. Это обстоятельство позволило создателям «волевых» теорий считать веру атрибутом воли (Р.Декарт, И.Г.Фихте). Как акт воли свободного выбора, страстного влечения понималась и в более поздних философских системах. «Вера, по мнению С. Къеркегора, не есть знание, а акт свободы, выражение воли». ( Цит. по: Выховский: Къеркегор 1972: 112).

Если в «эмоциональных» и «волевых» теориях веры заметно явное тяготение к иррационалистическому её пониманию, то создатели третьей группы теорий - «интеллектуальных», например, Г.В.Гегель, наоборот, рационализирует её природу до такой степени, что отождествляет со знанием.

Итак, названные здесь психологические теории веры, основы которых были заложены еще в классической философии, можно объединить под тем углом зрения, несмотря на все различия, что она в них рассматривается как особое внутреннее психическое состояние, постигаемое интроспекцией, как «душевный акт», особый тип “умственного действия» или "умственного явления».

Тот факт, что ни одна из этих теорий в отдельности не создает целостных представлений о ней, в философской литературе осмыслили её как структурное образование или состояние индивидуального и общественного сознания: охватывающего, концентрирующего в себе в преобразованном виде все элементы структуры человеческого «я» - рациональные или интеллектуальные, эмоционально-волевые и деятельно-практическое. «Вера есть целостное состояние субъекта, - определяет, например, А.К.Козырева, - входящее в структуру личности или теснейшим образом с ней связанное, концентрирующее воедино все стороны психики человека - и интеллектуальную, и эмоциональную, и волевую» (Козырева 2008: 157).

Таким образом, анализ веры как «факта» психики и сознания и как неотъемлемого элемента мотивационной сферы личности составляет наиболее разработанные на сегодняшний день - психологический и социально-психологический аспект её исследования. Очевидно, однако, что при всей значимости и правомерности такого рода анализа он вовсе не вскрывает гносеологической специфики веры, её особенности по сравнению с другими, близкими явлениями - знанием, заблуждением, мнением, а следовательно, не определяет её места в познавательном процессе.

Вера или верование (как результат), подобно любому элементу познания, в качестве его фиксированного этапа представляет собой гносеологический образ. В этом смысле оно (верование), как и все остальные гносеологические образы, - сложный синтез собственно отражательных, с одной стороны, и ценностных компонентов - с другой.

Если верование - результат отражения, то оно характеризуется, как и знание, и мнение или заблуждение, той или иной степенью адекватности, более или менее строго и точно оцениваемой познающим субъектом. Высокая точность оценки, т.е. истинность представляет собой возможность возникновения истинного верования, мнения и знания. И, наоборот, при недостаточно точной оценке степени соответствия, т.е. в случае преувеличения её или преуменьшения формируется неистинный гносеологический образ - заблуждение, которое 
при определенных условиях становится ложным мнением или закрепляется в виде ложной веры.

Итак, верования могут быть, подобно мнениям, истинными и ложными. Независимо от того, каким гносеологическим свойством верование обладает, оно принимается человеком, у которого оно сформировалось, в любом случае как истинное. В тех ситуациях, когда он «соглашается» с имеющейся у него информацией - истинной или ложной, познающий учитывает те или иные основания.

С отрицанием каких-либо оснований у веры связано и обычное описание её посредством слов типа «наивная», «слепая» и т.п. При этом считается, что наивная, слепая вера, в отличие от так называемой сознательной, смешивает себя со знанием, не являясь на самом деле им (Введенский 1894: 74).Такая вера представляется обычно чем-то некритически воспринятым, готовым, завершенным, раз и навсегда данным. Именно в этом смысле вере обычно отказывают в проверке, обосновании, её как бы «бронируют» от критических и логических нападок.

Хотя выявленная традиция - отрицание у верования каких-либо оснований достаточно распространена в философской литературе, она представляется неправомерной. Дело в том, что у любой веры основания также имеются, но они носят особый характер. Их особенность заключается в субъективности, а следовательно, в недостаточности и интерсубъективной необязательности. «Вера имеет характер чисто субъективный, - подчеркивает О.Д.Хвольсон, - она покоится на основаниях, достаточных только в субъективном отношении, т.е. достаточных для того лица, которое верит. И нет возможности сделать веру обязательной для другого лица. Поэтому безрассудной и бесцельной является попытка насильно заставить кого-либо верить во что-либо». (Хвальсон 1916: 2).
Новая волна критики устоявшихся верований поднялась в период зарождения научных знаний в новое время и замены ими религиозной идеологии. Вслед за Ф.Бэконом, наиболее скрупулезно проанализировавшем их в виде известных «идолов», Р.Декарт призвал ученых принять решение отречься от всех суждений, принятых ранее на веру.

Такое отношение, порой резко отрицательное, к укоренившимся верованиям, постоянное стремление разрушить их, элиминировать из сознания людей, характерное и для последующих этапов развития философии, не мешало, однако, признанию факта их успешного функционирования в практической деятельности людей. Р.Декарт, выработавший в Новое время наиболее влиятельный в западноевропейской культуре идеал познания - истинного, достоверного, ясного и отчетливого знания, признавал практическую значимость и вероятность знания. Он считал, что «если мы не можем выработать себе самых верных взглядов, мы должны придерживаться наиболее вероятных; и пусть мы не усматриваем большего вероятия одних перед другими, мы должны тем не менее остановиться на какихлибо взглядах и затем уже рассматривать их не как сомнительные, поскольку дело будет касаться практики, но как вполне истинные и достоверные...» (Декарт 1995: 277).

Итак, вера или верование - это гносеологический образ, характеризующийся как истинностью, так неистинностью и субъективностью, следовательно, недостаточностью оснований, а нередко - и их невыявленностью, неосознанностью, смутностью. Верование при отсутствии истинности и объективной обоснованности, даже при обнаружении этого отсутствия, не разрушается, а продолжает успешно функционировать в практике, поскольку оно и не предполагает их по своей природе. Проведенное уточнение специфики веры как феномена познания, а ранее - уточнение природы и 
гносеологических характеристик знания позволяет рассмотреть теперь их соотношение.

Проблема соотношения знания и веры была одной из самых популярных, но вместе с тем и самой сложной и запутанной в классической философии. И дело, конечно, вовсе не в субъективных действиях её исследователей, которые, по мнению Г.Райла, якобы склонны усложнять и запутывать себя и своих читателей относительно различия между знанием и верой (Ryle 1966: 128). Трудности анализа их взаимосвязи возникали также не в результате непонимания семантических особенностей соответствующих слов естественного языка.

Ошибочность в анализе проблемы соотношения знания и веры в философии вызвана неверными принципами исследования: реальной многогранностью как взятых в относительной изоляции друг от друга знания и веры, так и их тончайшими переплетениями, взаимными переходами в реальном познавательном процессе. Существуют различные интерпретации их взаимосвязи. Как подмечает Г.Райл, некоторые философы различают их только по степени того и другого, другие же - по присутствию в одном из них такого «интроспективного ингридиента» (Ryle 1966: 128), Трудности который отсутствует в другом. Однако в психологическом плане знание, вера и мнение сходны между собой, поскольку их объединяет такой структурный элемент их природы, как уверенность в истинности. «Человек, который знает что-либо, - утверждает Г.Г.Прайс, - абсолютно уверен в этом; и человек, который только верит без знания, тоже может быть абсолютно уверен в этом. Он может иметь высокую степень веры - полное убеждение» (Price 1969: 83).

Вместе с тем невозможно, конечно, игнорировать зависимость меры интенсивности уверенности от характера оснований, от степени очевидности и достоверности. «...Разумный человек, - подчеркивал Д. Юм, - соизмеряет свою веру с очевидностью (Юм 1995: 111). Несмотря на эту зависимость, любая попытка разграничить знание и веру по интенсивности уверенности не устанавливает их гносеологического различия. Это различие состоит, как следует из сделанных уточнений, в характере оснований, в степени достоверности.

Таким образом, при сопоставлении основных гносеологических характеристик знания и верования как фиксированных познавательных результатов выясняется, что если знание это гносеологический образ - истинный, достаточно объективно и субъективно обоснованный (основания выявлены), то вера - это тоже гносеологический образ, который может быть как истинным, так и ложным и недостаточно объективно обоснованным.

Уточнение гносеологических характеристик позволяет рассмотреть вопрос о возможности и правомерности определения знания в терминах веры. В силу своей «неполноценности» «вера» не может считаться розовым понятием в дефинициях знания. Определение знания как «истинного, оправданного верования», всё еще имеющее место в современной западной философской литературе, следует рассматривать как своеобразный анахронизм, доставшийся (конечно, в преобразованном виде) от его религиозных интерпретаций.

Соответствующие категории - «знание» и «вера» однопорядковы по степени общности, поэтому методологически неверно было бы определять их друг через друга. Для их определения в категориальном аппарате гносеологии существует философская категория образа, охватывающая как знание, так и сопутствующие, но не разнозначные ему результаты познания. По этой же причине нельзя определять и веру (конечно, при более строгом подходе) как особое знание. При уточненных характеристиках знания и веры можно решить также вопрос о возможности и познавательных механизмах их взаимоперехода. Исходя из рас- 
пространенного понимания того и другого, ответ на вопрос: “Что должно быть добавлено к истинной вере, чтобы она стала знанием?», заключается в первом приближении в том, что при достижении обоснования истинная вера становится знанием, а, точнее, при дополнении субъективных оснований объективными.

ЦИТИРОВАННАЯ И УПОМЯНУТАЯ ЛИТЕРАТУРА

1. Аверин, А.И. (1998). Ценностно-познавательный характер знания, мнения, веры и убеждения. // Ценностные аспекты отражения. Свердловск.

2. Аристотель (1983). Соч.: В 4-х т., т. 2. М.: Мысль.

3. Борунков, Ю.Ф. (1989). Убежденность и вера. М.: Наука.

4. Букин, В.Р., Ерунов, Б.А. (1974). На грани веры и неверия. Л.: ЛГУ.

5. Введенский, А. (1894). «0 видах веры в её отношении к знанию». Вопросы философии и психологии. Пг., Кн.22(1).

6. Вера. (1952). - В кн.: Словарь русского языка. М.: ЭКСМО.

7. Вера. (2000). - В кн.: Новая философская энциклопедия. т.1.М.: Мысль.

8. Волов, А.Г. (1973). Знание и мнение как гносеологические категории. Автореф. дис. канд.филос.наук., Таллин. Геворкян, А.А. (1987). Очерк исторической методологии науки. Ереван: АН Арм. ССР.

9. Геворкян, А.А. (1978). Очерк современной теории знания. Ереван: АН Арм. ССР.

10. Геворкян, А.А. (2010). Философия. Наука. Культура. Ереван: Изд. «Гитутюн» НАН PA.

11. Гегель, Г.Ф. (1974). Энциклопедия философских наук. Т.1. М.: Мысль.

12. Гегель, Г.Ф. (1935). Соч., М., т. Х1.

13. Гегель, Г.Ф. (1956). Соч., М., т. 3.
Более сложно предстает обратный процесс, т.е. переход знания в веру. Это происходит при «потере» того, что считалось знанием, доказательности и обоснованности, связанной с обнаружением новых данных, пересмотром старых оснований, критериев оценки и т.п.

14. Губенко, В.И. (1975). «О вере и верных знаниях». Философские науки. № 1.

15. Декарт, Р. (1995). Избранные произведения. - М.: Университет.

16. Ерунов, Б.А. (1971). «Познавательные значения мнения». Вопрос. Мнение. Человек. - Уч.зап. Лен.гос.пед.ин-т, 1971, T.497;

17. Ерунов, Б.А. (2003). Мнение в системе человеческого познания. СПб.: Педагогика.

18. Желнов, М.В. (2001). Критика гносеологии современного неотомизма. М.: Университет.

19. Кант, И. (1998). Соч., т. 3. М.: Университет.

20. Козырева, А.К. (2008) Природа веры. М.: Университетский проект.

21. Козырева, А.К. (1988). «Природы веры». Философские исследования. Уч. зап. /Лен. гос. пед. ин-т/. М.: Педагогика.

22. Копнин, П.В. (1974). Гносеологические и логические основы науки. М.: Наука.

23. Крымский, С.Б. (1974). Научное знание и принципы его трансформации. Киев.

24. Локк, Д. (1987). Избранные философские произведения, т.2. М.: Университет.

25. Манасян, А.С. (1973). Проблеы развития научного знания. Ереван, Изд. АН Арм. CCP.

26. Оганян, К.М. (1990). Генезис и развитие теоретического уровня естествонаучного знания. Ереван: Изд. АН Армении.

27. Оганян, К.М. (1984). «Природа и основные характеристики научного знания». 
Вестник общественных наук АН Арм. ССР. Ереван, -№ 11.

28. Платон. (1971). Соч.: В 3-х т., т. 3(1). - М.: Мысль.

29. Соколов, В.В. (1999). Средневековая философия. М.: Университет.

30. Спиноза, Б. (2003). Избранные произведения, т.1. М.: Университет.

31. Хвальсон, О.Д. (1916). Знание и вера в физике. Пг.

32. Хомутовский, Ф.К. (1971). К вопросу о вере в познании. М.: Наука.

33. Быховский, Б.Э. (1972). С. Къеркегор. М.: Мысль.

34. Щербаков, Г.В. (1972). Убеждение в его отношении к знанию и вере: Автореф. дис. канд. филос. наук - Томск.
35. Юм, Д. (1995). Соч.: в 2-х т., т.2 М.: «Канон».

36. Armstrong D. (1973). Belief, truth and knowledge. Cambridge.

37. Ayer, A. (2006). The problem of knowledge, Ld.

38. Belief. (2002). -Jn.: Websters new world dictionary of American language. $\mathrm{Ld}$.

39. Popper, K. (1972). The objective knowledge: An evolutionary approach. - Oxford: Cbarendon Press.

40. Price, H. ( 1969). Belief. Ld.

41. Ryle, G. (1966). The concept of mind. Ld.

42. Rynin, D. (1967). Knowledge, sensation and certainty. - Jn: Epistemology. New essays in the theory of knowledge. /Ed. by A. Stroll.

ОГАНЯН КАДЖИК

\section{ВЗАИМОСВЯЗЬ ЗНАНИЯ, МНЕНИЯ И ВЕРЫ: ГНОСЕОЛОГИЧЕСКИЙ АНАЛИЗ}

\section{PEЗЮME}

Рассматривается взаимосвязь знания, мнения и веры как различных форм познавательной активности и как гносеологический продукт (явление). Автором показана эволюция взглядов на проблему соотношения веры и знания в истории социально-философской мысли. Проанализирована природа знания, его неотъемлемые свойства, наряду с другими результатами познавательного процесса. Показано отличие знания от других эпистемологических форм, единство характеристик, истинность и достоверность (обоснованность). Аргументировано, что свойства знания носят не абсолютный, а относительный характер, поскольку они изменяются. Также меняются гносеологические ценности в обществе и гносеологический идеал. В результате научная модель знания представляет собой своего рода гносеологический идеал в тенденциях. В реальной познавательной практике, знание выступает в виде различных своих модификаций, в том числе, незрелых форм типов мнения: верования, предположения, догадки, предрассудки, предубеждения, а в зрелой форме знание превращается в истинное убеждение. В результате анализа происходит переоценка критериев взаимосвязи знания, мнения и веры.

Ключевые понятия: гносеологический продукт, взаимосвязь знания, веры и мнения, гносеологическая ценность, гносеологический идеал, познавательная практика, истинность и достоверность, заблуждение, субъективная 


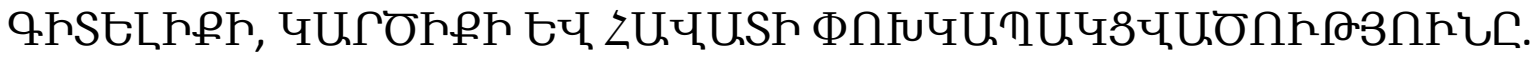

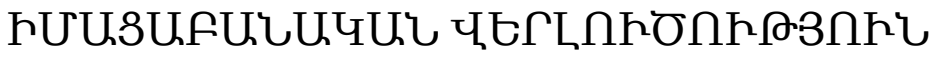

\section{UUФกФПధU}

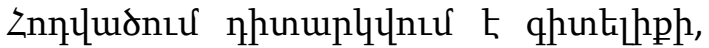

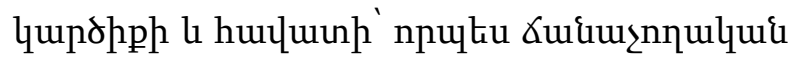

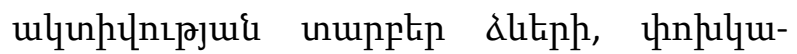

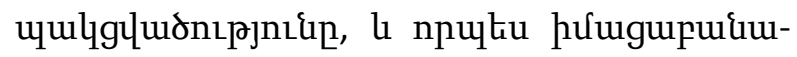

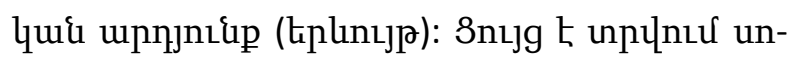

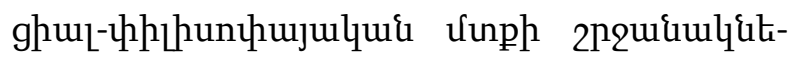

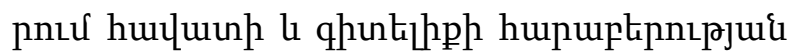

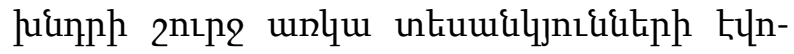

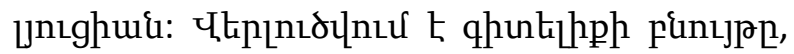

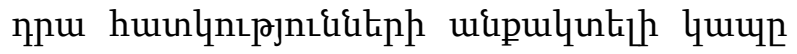

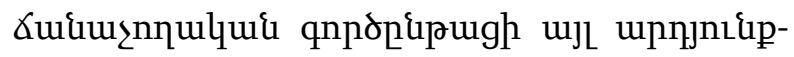
\{tiph htiun: 3nıjg Ł unpunud qhuntihph unuppt-

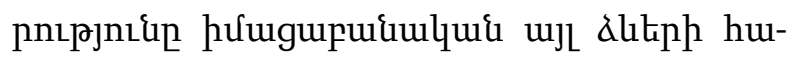

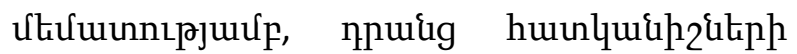

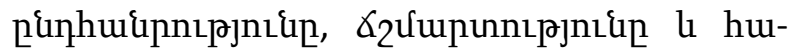

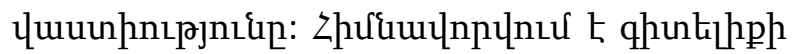

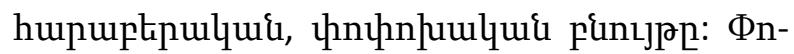

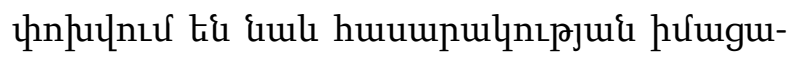

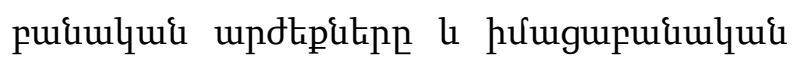

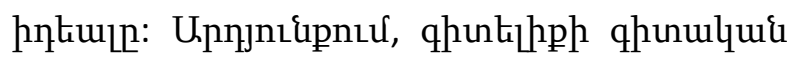

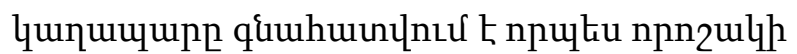

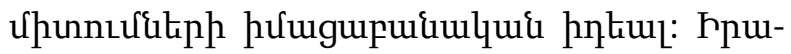

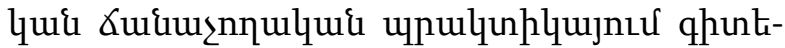

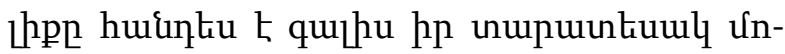

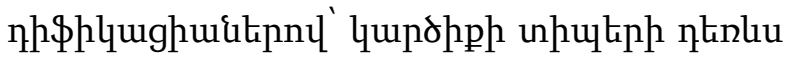

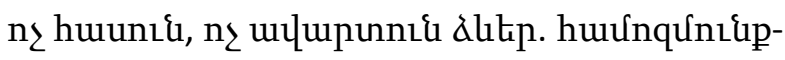

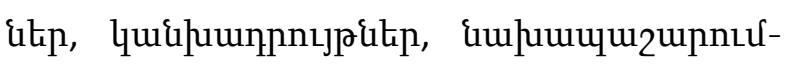

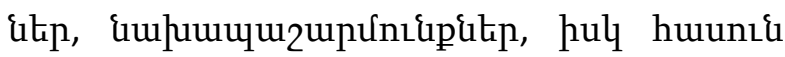

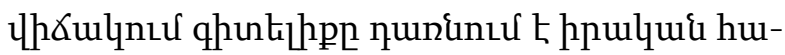

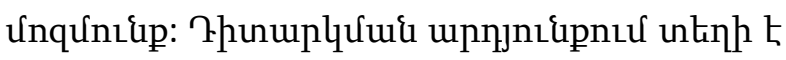
nufitinnu qhuntihph, qundhph le huluunh

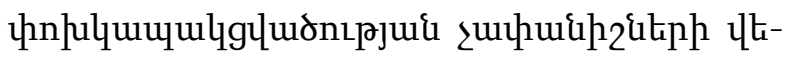
puiquuhuunnıu:

Zuikqnıgujhi huulqugnıpjnıkitip. hưu-

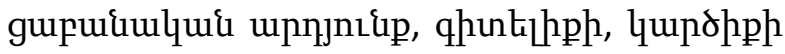

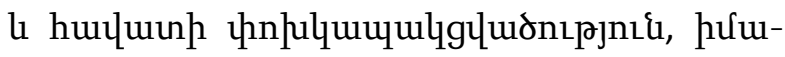

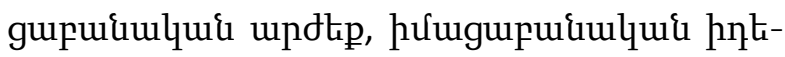

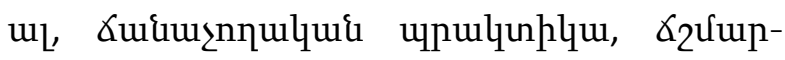

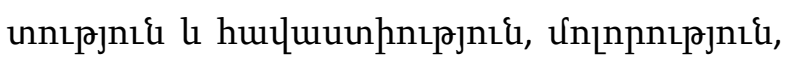
unıpjtilunhl uhuul, upnupugnıu, huluunh

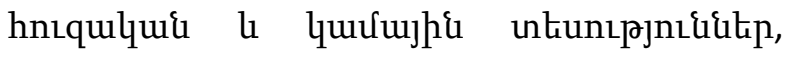

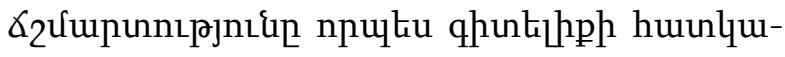
\{1.2: 


\section{THE INTERCONNECTION OF KNOWLEDGE, OPINION AND BELIEF: GNOSEOLOGICAL ANALYSIS}

\section{SUMMARY}

The interrelation of knowledge, opinion and belief as various forms of informative activity and as a gnoseological product (phenomenon) is considered. The author showed evolution of views of a problem of a ratio of belief and knowledge in the history of social- philosophical thought. The knowledge nature, its integral properties, along with other results of informative process is analyzed. Difference of knowledge from other epistemological forms, unity of characteristics, the validity and reliability is shown. It is reasoned that properties of knowledge are carried not absolute, but by relative character as they change. Also gnoseological values in society and a gnoseological ideal change. As a result the scientific model of knowledge represents some kind of gnoseolo- gical ideal in tendencies. In real informative practice, the knowledge acts in the form of various modifications, including, unripe forms of types of opinion: beliefs, assumptions, guesses, prejudices, prejudices. And in a mature form the knowledge turns into true belief. As a result of the analysis there is a revaluation of criteria of interrelation of knowledge, opinion and belief.

Key concepts: epistemological product, relationship between knowledge, beliefs and opinions, epistemological value, epistemological ideal, cognitive practice, the validity and reliability, error, human error, justification, emotional and volitional theory of faith, truth as a characteristic of knowledge. 